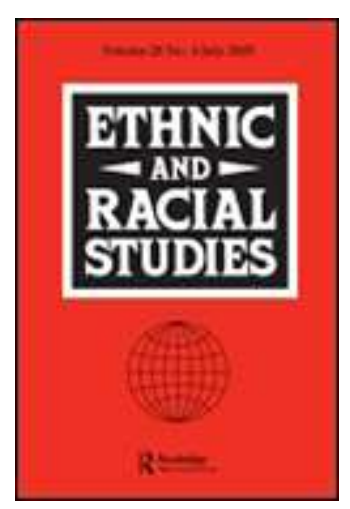

\title{
Nationalism, National Identity and Territory: Jacint Verdaguer and the Catalan Renaixença
}

\begin{tabular}{|r|l|}
\hline Journal: & Ethnic and Racial Studies \\
\hline Manuscript ID: & RERS-2006-0050.R5 \\
\hline Manuscript Type: & Original Manuscript \\
\hline Keywords: & Nationalism, Nation, Territory, Catalonia, Verdaguer, Historic Bloc \\
\hline & \\
\hline
\end{tabular}

\section{s) ScholaroNE}

Manuscript Central 


\title{
NATIONALISM, NATION AND TERRITORY: JACINT VERDAGUER AND THE CATALAN RENAIXENÇA
}

\begin{abstract}
This paper seeks to explain the historic importance to Catalan nationalism of the nineteenth-century poet and priest, Jacint Verdaguer. In order to do so, rather than focus on his contribution - and that of the wider cultural revival, the Renaixença to the development of the Catalan language as the basis for national political mobilisation, this paper argues that we cannot fully understand Verdaguer's importance without reference to his role in constructing a geographical narrative linking nation and territory. At the same time, given that national meanings are always contested, the paper proposes a dialectical approach to nationalism that situates the work of writers within the context of power struggles between social groups. Consequently, Veradguer's centrality to Catalan nationalism is ultimately explained by his role in producing a geographical narrative capable of attracting important sectors of rural Catalonia to the hegemonic project of the industrial bourgeoisie.
\end{abstract}

\section{Key words}

Nationalism; Nation; Territory; Catalonia; Verdaguer; Historic Bloc. 


\section{Introduction}

The year 2002 saw the centenary of the death of one of the most remarkable figures of Catalan literature, Father Jacint Veradguer, wayward priest and epic poet. He was, and is, considered by many to be the crowning glory of the Renaixença, the cultural and literary movement inspired by Romanticism that led to a renewed Catalan cultural awareness and that, in turn, provided the basis for the reawakening of Catalan political consciousness. During his own lifetime Verdaguer achieved widespread fame, primarily for his literary achievements that included his 'appointment' as Catalonia's national poet, although his eccentric lifestyle would also make him the subject of popular myth.

In order to commemorate the centenary of his demise the Department of Culture of the Generalitat de Catalunya (the regional government of Catalonia) organised l'Any Verdaguer, a year-long series of activities based on the works of the author, such as readings, debates, lectures, exhibitions and so forth. Such was the success of l'Any, that the organisers were forced to prolong it for six months. In the light of this enduring popularity, this article seeks to address the question of how we are to understand the centrality of Verdaguer, and the Renaixença, for Catalan nationalism.

The majority of contemporary accounts of Catalan nationalism have focussed on language as a central pillar around which nationalist mobilisation has taken place (see, for example, Balcells 1992; Conversi 1997; Fontana 1998; McRoberts 2001; Guibernau 2002), which reflects the stress placed by Catalan nationalists themselves on the centrality of this element of national identity. Thus, from this perspective one way of understanding Verdaguer's importance to Catalan nationalism is to stress his role in the forging of a language of literary and hence 


\section{Nations, Nationalism and Territory}

Geographical considerations lie at the heart of how nations and nationalisms operate. Politically, the most significant claim that nationalism makes on behalf of the nation is that the latter should be 'masters of their own homelands' (Kaiser 1994, p. 3), that is, the nation should exercise political power, usually in the form 
of state sovereignty, over a given territory ${ }^{1}$. Such territorial claims - claims to material belonging - made in the name of the nation are based on purported symbolic belonging, whereby, on the one hand, the nation's defining characteristics - national identity - are held to be a result of its relationship with a given territory, while the territory in question cannot be conceived without reference to its relationship with the nation. In this way the nation is effectively territorialised and the territory nationalised and thus becomes the homeland, with both nation and homeland coming into being through this relationship of mutual belonging. In the words of Steven Grosby, the nation's very existence is predicated upon the existence of a collective consciousness constituted by a belief that there is a territory which belongs to only one people and that there is a people which belongs to only one territory' (2002, p. 27).

National homelands are understood as territories with relatively fixed borders that display a relatively high degree of internal sociological homogeneity, and are clearly distinguishable from other territories. At the same time, they are larger than individual localities, such as cities, towns and villages, and while individual members may identify with other spatial scales, be they local, regional or even supranational, identifying with and loyalty to the national scale takes precedence over all others (Grosby 2002).

National homelands come to be the 'cultural container' (Taylor 1999) of the nation to which identity is attached, and is at once the source and the reflection of the nation's unique identity. In English nationalist discourse, for example 'quintessential national virtues' are said to be reflected in the English landscape of country lanes, hedgerows and cottages (Lowenthal 1994, p. 20), while insularity has protected the English from the (European) continental afflictions such as 
'rabid dogs and dictators alike' (Tebbit quoted in Lowenthal 1994, p. 22). At the same time, apparently a-spatial, cultural elements of national identity, such as a shared language or history, come to be understood as mediating elements in this relationship, and are thus spatialized. For Fichte, the German language was so important, since, unlike its Romance counterparts such as French, it

\begin{abstract}
derived entirely from Germanic elements, originally coined to describe the world still inhabited by Germans. This language, therefore, was immediately transparent and comprehensible to all German speakers, placing them in immediate relationship with their environment and with each other (Geary 2002, p. 25).
\end{abstract}

\title{
Nations and Territories as Constructs
}

The relationship between nation and territory is generally considered by nationalists to be 'immutable', stretching back to the mists of time (Penrose 2002), and primordial in the sense that national attachment to and control of a given homeland forms part of the natural world and the human condition. Despite the practical problems involved in putting this principle into practice (historically very few states have been coterminous with a single nation), it constitutes the organising principle of the world system of states and has become the 'commonsense' way of interpreting geopolitical space. Thus, while conflicts over competing national claims to territory are generally condemned as atavistic (Billig 1995), the underlying principle - that nations and territories somehow belong to each other - has generally remained unchallenged. Indeed, in our daily language 
we effectively elide and reify territory and nation when talking of how 'Britain faces unprecedented challenges' or how 'Catalan is the language of Catalonia'.

This common-sense understanding of the geopolitical world is also, I believe, implicit in the majority of mainstream approaches to the subject of nations and nationalism from disciplines such as history, anthropology, sociology and political science, although this is not to say that territorial considerations are entirely absent. Ernest Gellner, for example, understands nationalism as 'a theory of political legitimacy, which requires that ethnic boundaries should not cut across political ones' $(1983$, p. 1), that is, the boundaries of the state as a territorial political unit should coincide with those of the nation, a cultural community; accounts based on uneven economic development and internal colonialism use spatial categories such as national peripheries and internal national colonies (see, for example Hechter 1975; Nairn 1977); one of the most enduring categorizations of nations and nationalisms uses the category of 'territorial nations' as a synonym of 'civic' - as opposed to 'ethnic' - nations (Kohn 1944; Brubaker 1992); while one of the key elements of national identity for many authors has been the 'possession or occupation of a historic homeland' (Smith 2004, p. 18; see also, for example, Stalin 1975). Yet such accounts generally fail to explain why and how nations come to be related to 'their' territories, and as such the former are, in effect, presented as spatial 'givens', since these accounts fail to challenge the nationalist proposition regarding the mutual belonging between these two categories.

However, over the last two decades or so there has been an increasing degree of awareness, mainly but not exclusively, among human and political geographers of the importance of the spatial dimension of nationalism and the 
nation $^{2}$. The emergence of this body of literature is due - at least in part - to more critical approaches to geography that, inter alia, have challenged the dominant idea that spatial categories such as nations are 'natural and eternal features of the geopolitical landscape' (Kaiser 2001, p. 323), and have stressed the constructed, historically-contingent nature of nations and homelands. Thus, Ansi Paasi territorial units such as national territories are seen as 'historical products - not merely in their physical materiality but also in their socio-cultural meanings. Hence territories are not eternal units but, as manifestations of various institutional practices, emerge, exist for some time and disappear' (1995, p. 3).

In this sense several scholars argue that national homelands can only be found in the Modern Age, since before that time there was little correspondence 'between territories, regions or kingdoms, and ethnic groups who occupied them' (Geary 2002, p. 37), and even where attachment to the land was common among the population, this was limited to the 'immediate place of living' such as valleys, uplands or lowlands. The 'imagining of an overall "country", in which lived-in localities are united within a wider homeland, does not seem to have been typical in pre-modern Europe' (Billig 1995, p. 74) ${ }^{3}$.

Equally, from the point of view of elite perceptions of territory, Peter J. Taylor (1999) argues that the nationalisation of territory has its origins in the 1793 French Constitution that obliged the state to defend every corner of the national homeland, in contrast to preceding conceptions of state territory that allowed for parcels of land to be transferred between states as the outcomes of wars. However, it was not until the late nineteenth century that popular identification with national territory became widespread in states such as France (Weber 1976), Germany (Kaiser 2001), Italy and Spain (Mac Laughlin 1986) coinciding with a general 
trend in the West whereby states markedly increased their power to penetrate, both socially and spatially, their respective societies (Mann 1993). It is at this time that national cultural identities and political obligations take on the very same spatial contours as state sovereignty itself.

A further point here is that, even if the mutual relationship of symbolic belonging that brings nations and homelands into being could be considered to be a naturally-occurring phenomenon, for some it is far from 'natural' that territorial belonging should necessarily imply territorial control, as nationalists themselves claim. Such a proposition would appear to be premised on the idea that the nation somehow displays a collective, in-born territorial instinct. Yet as Robert D. Sack (1986) so powerfully argues, such a 'territorial instinct' is not a socio-biologically determined impulse, but rather it is a strategy that can be and, more importantly, has been switched on and off at different points in time and space, and it is through such historically-contingent strategies, and only through them, that territories come into being.

\section{National Territorial Construction}

This spatial alignment of national identities and loyalties with political power did not, of course, arise spontaneously. Since at least the mid nineteenth century, both state-sponsored and non-state nationalisms have made conscious efforts to produce and reproduce the national territory and the territorial nation, thus promoting the idea that their respective nations and territories - both real and potential - belong to each other in symbolic and thus material terms, a process that can be referred to as national has been referred to as national territorial construction. The literature on the subject generally breaks this process down into 
two complimentary ones: one the one hand, 'the national construction of social space' (Williams and Smith 1983) or 'the national territorialization of space' (Kaiser 2001) involve projecting national meaning onto space in order to construct national homelands; on the other, 'national territorial socialization' (Paasi 1996) or 'territorial nationalization' (Kaiser 2001) refer to how national territories themselves and their associated components, such as boundaries, are used to socialise the national population as members of a differentiated, exclusive territorial group. Given the ultimate objective of this paper, I shall focus here on the former, that is, means used by both state and non-state nationalisms to construct the national homeland, although in practice both processes are at work simultaneously.

Historically, one of the most important means used in this respect has been the presence of national institutions themselves. Initially, we can understand the territorial expansion of these institutions, their presence and accompanying symbols, such as national flag, as a means of claiming territory in the name of the nation. Over time, if national hegemony is established, their presence becomes 'unnoticed', part of the landscape, and thus all the more powerful as means of reproducing the nation spatially.

The education system that emerged in the second half of the nineteenth century can also be understood as making a vital contribution to the process of national territorial construction. It was the newly institutionalised academic disciplines such as sociology, political science, economics and geography that not only had their 'origins in the practical interests of the state' (Agnew 1987, p. 74), but also developed a methodological nationalism, whereby nation and state were conflated and this spatial level came to be considered the only appropriate one for 
the study of society, to the detriment of the local, sub-national regional and even global level (Hooson 1994). In addition, geography was one of the subjects introduced into all school curricula when compulsory schooling was established in late nineteenth-century Europe, precisely as a means of promoting a sense of national identity among citizens, since 'the future citizen had to learn to link an abstract idea (the nation) with a concrete and tangible reality, that is, the physical and spatial setting of the nation' (Hooson 1994, p. 7. See also Nogué i Font 1991; and Johnston et al. 1988).

Other academic disciplines also contributed to the process: historians effectively spatialized national history by conflating the history of the nation - of the Britons, for example - with that of the national territory - of Britain - thus reinforcing nationalist claims concerning the ancient nature of the nation's bond to the homeland. Similarly, what Geary calls 'ethnoarchaeologists' rallied to the cause by presenting their findings not only as 'proof' of the links between the present nation and its ancestors, but also to justify nationalist claims over territory (2002, p. 35).

At the same time, a whole host of nationalist-inspired writers, landscape artists (Lasserre 1993; Osborne 1988), poets (Billig 1995) and composers (Rose 1995; Storey 2001) would all contribute to this process of national territorial construction by identifying the extent of national homeland and praising its beauty as a whole or that of special places or regions within it that were considered the spiritual reserve of the nation.

\section{The Dialectics of Territorial Nationalism}

As we shall see in the second half of this paper, Verdaguer and the wider 
Renaixença the major contribution of to Catalan nationalism is that they construct a symbolic relation between the Catalan nation and the national homeland. However, in itself this does not explain their historic importance for Catalan nationalism. Contrary to nationalist thinking, national territories and their corollary, territorial nations, do not have 'meanings that are natural' (Cresswell 2004, p. 27), waiting to be identified and brought to life by figures of literary genius, but rather ones that are contested. Consequently, in order to understand why a particular national narrative achieved centrality for early Catalan nationalism, we must place it within the context of power struggles between different social groups, which in the case of nineteenth-century Catalonia leads us to analyse the attempts by one group, the industrial bourgeoisie, to achieve leadership or hegemony. Hegemony, according to Gramsci (1971) is achieved by a group in society when they achieve not only dominance - control over the means of coercion of the state - but also the consent of subordinate groups who are essentially persuaded that the interests of the leading group are those of society as a whole.

This Gramscian understanding of hegemony provides the conceptual and theoretical basis for a dialectical approach to nationalism developed by Jim Mac Laughlin (1986; 2001) who understands nationalism as a political movement aimed at establishing the hegemony of the bourgeoisie in late nineteenth- and early twentieth-century in Europe. The relationship between nationalism and the bourgeoisie is, of course, contentious (see, for example, Anderson 1988; and Hroch 1985), although, in the case that interests us here, that of Catalan nationalism, the industrial bourgeoisie were very clearly involved with nationalism from its beginnings in the nineteenth century, and, notwithstanding, 
the theoretical and methodological advantages of the dialectic approach outweigh, I believe, possible objections to the substantive argument.

Following Raymond Williams (1973), Mac Laughlin contends that any contemporary Marxist account of nationalism must come to terms with 'the complex Marxist problematic of base and superstructure' (1986, p. 306). This is 'problematic' in the sense that certain readings of Marx have insisted that the economic base is essentially determining, since it represents a force that is external to human beings and yet 'prefigures' 'predicts' and 'controls' outcomes (Williams 1973, p. 4). However, as Gramsci himself showed in his work on Italian history, 'economic factors by themselves seldom explain the complexity of sociopolitical or indeed regional reality' (Mac Laughlin 1986, p. 314). Thus, while the economic base - the means and relations of production - ultimately set the limits for substantive outcomes, if we are to explain historical phenomena - in this case specific forms of nationalist mobilisation - we must focus on 'the role of human agency, political leadership, organizations, ideologies and superstructural institutions in the historical process' (Mac Laughlin 1986, p. 314) and this must be done in specific historical and spatial contexts, since it is here that structure and agency ultimately come together and interact in a dialectical way. Consequently, he rejects the economic determinism and reductionism inherent in structuralist and neo-Marxist accounts of nationalism, since they reduce nationalism to the end product of changes in the economic bases of society.

Mac Laughlin also takes issue with what he calls idealist or autonomous accounts of nationalism by scholars such as Anthony Smith for effectively reifying the perceived cultural attributes of the nation and for attributing historical agency 'not to human but to structural elements, and the middle-class 
intelligentsia, depicted as a mere trajectory of underlying ethnic and cultural forces, is seen to operate in a socio-economic, political and ideological vacuum' (Mac Laughlin 1986, p. 310).

Overall, a dialectical approach to nationalism allows us to understand the latter neither as the inevitable result of the rise to power of the a given social group, nor as an autonomous force, but rather as the terrain on which political and ideological struggles take place between groups, within the limits placed by economic structures and changes therein. From this perspective, then, the second half of this paper article analyses the geographical narrative proposed by Verdaguer and argues that his centrality to nineteenth-century Catalan nationalism rests on his ability to promote the ideological hegemony of the industrial bourgeoisie by symbolically incorporating important sectors of rural society into an historic bloc. This avoids the problems associated with many accounts of Catalan nationalism of this time that are either reduce Catalan nationalism to the manifestation of the rise to power of the Catalan industrial bourgeoisie (Solé-Tura 1970; Kark 2007), or reify the Catalan language culture and consequently stress the role of the intelligentsia in creating a cultural movement capable of (re)awakening the nation (Balcells 1992; Conversi 1997; McRoberts 2001; Guibernau 2002).

\section{The Origins of the Renaixença}

La Pàtria, a poem by Bonaventura Aribau, is generally considered to be the starting point of the Renaixença, since it was one of the very first poems for decades written in Catalan to be published. However, from a territorial perspective the poem is also of undoubted interest. In the poem Aribau begins to outline some 
of the key themes of the Renaixença, namely a love of the pàtria, whose natural beauty is praised and even personified, and the close relation that he establishes between the pàtria and the Catalan language: 'Aribau identifies language and pàtria in a symbiosis that the Renaixença would only accentuate. If the pàtria is recovered in the heart, so is its language' (Pi de Cabanyes 1984, p. 48).

When the literature of the Renaixença was institutionalised in the Jocs Florals ${ }^{4}$ of 1859 , held, significantly, in Barcelona it was works on the home or the Catalan mountains ${ }^{5}$, based on the primary identification between Catalonia and traditional country life, that marked the territorial expansion of the poetry of the Jocs' (Fradera 1992, p. 163). The insistence on an idyllic rural life and the 'bon pagès'(good farmer) ${ }^{6}$, were not just about the juxtaposition of tradition with the moral and material degeneration associated with modernity, but also permitted the Renaixença to fuse elements of national identity, such as traditions, language and so forth with the homeland, the Catalan terra. After all, who is closer to the earth than the 'good farmer'? This was no more evident than the spectacular apparition of Jacint Verdaguer, who in 1865 presented himself at the prize-giving ceremony of the Jocs Florals in country attire, complete with a barretina, a traditional floppy red cap worn by shepherds in Catalonia.

\section{Verdaguer's Canigó}

Verdaguer himself was from a village close to Vic, considered to be the capital of rural Catalonia and whose diocese was at the centre of an ideological movement, vigatanisme, an important cultural and intellectual school of thought, inspired by the works of Catholic philosopher Jaume Balmes (1810-1848), In terms of its ideological content, vigatanisme was like many other traditionalist tendencies of 
the time, in that it extolled the virtues of country life and traditional social hierarchies (including the monarchy), and stressed the centrality of the Catholic Church in all aspects of daily life. Consequently, it opposed the modernisation of the Spanish state, though not necessarily Spain itself, and the modernisation of Catalan society (see, for example, Torras i Bages 1981). In addition to Verdaguer, other activists such Canon Jaume Collell, writer and editor of the widelycirculated newspaper, La Veu de Montserrat, (the Voice of Montserrat), made it possible to reach out beyond the strictly local ambit to all of Catalonia and, most importantly, to Barcelona (Ramisa 1985).

Of all Verdaguer's work, it is perhaps his epic Canigó that represents the greatest contribution to the process of the territorial construction of national identity. Published in 1886, at an overall level Canigó is a mixture of local legends and myths of the mountain that had formed part of 'Catalan' territory until the Treaty of the Pyrenees saw it was handed over to France in 1659. These tales are skilfully intertwined by the author with the Romantic historical version of the birth of Catalonia and the expulsion of the Moors. The main characters are the result of this mixture: Guifré de Cerdanya is a Count who wages war against the Moors, and kills his nephew, Gentil, lover of Flordeneu, due to the latter's betrayal of the homeland; Gentil's father, Tallaferro, a warrior like his brother, is joined by the third brother, Oliba, the abbot bishop, who leaves Canigó to found the monastery of Ripoll, which, as we shall see, is of enormous importance in defining the kind of territorial identity of Catalonia that Verdaguer proposes in Canigó.

In Canigó national territorial construction takes place on two levels: on the one hand, the geographical extent of the national homeland or pàtria is identified 
and its beauty praised, while on the other, a historical interpretation of the pàtria is introduced, based on the role of God and the Church. Turning to the first process, perhaps the most eloquent statement of the territorial intentions of Canigó is reflected in the dedication at the beginning of the work to 'the Catalans of France', which thus establishes the mountain of Canigó as part of the Catalan homeland, as indeed it was for several centuries before being ceded to France in 1659. In the fourth book, Lo Pireneu, Flordeneu and Gentil look out from their mountain perch over 'all the lands that my heart loves': the Pyrenean mountains of Minstrels, Puigmal, Noufonts, the Cadí range and Pedraforca, along with the woods, forests, waterfalls and mountain. The Pyrenean heights are like

\begin{abstract}
A great tree whose powerful branches/ reaching out from Valencia to Roses, weaving together the hills and peaks/ on which there hang, like everlasting flowers/ the white hamlets and villages/ and closer to the heavens, the hermitages/ that seem, up on high, to be their steps (Verdaguer 1997, p. 80).
\end{abstract}

For Verdaguer, like many other nationalist writers at the time, the extension of Catalan territory coincides with the medieval conquests of Jaume I, today known as the Països Catalans, the Catalan Countries ${ }^{7}$. But Verdaguer does not stop at merely pointing out such places, but running through this passage, and many others of the work, are many geographical, geological and botanical references that give account of the immense natural beauty of the Catalan lands. These references are skilfully blended with local legends to create a highly mythical, idealised vision of national territory, and established mountainous 
Catalonia, la Catalunya muntanyenca, with Vic as its capital, as the spiritual reserve of Catalonia.

However, as important as the Romantic vision of the Catalan homeland might be, Canigó offers a second level of analysis which goes beyond the 'mere' recognition of the territorial extension and its natural harmony, to include a religious interpretation of its construction, entirely in keeping with Verdaguer's own beliefs and those of his fellow vigatans. In this sense, we observe how geography and history are essentially fused, as the Catalan homeland becomes the stage on which the Christian 'Reconquest' takes place against the Moorish invaders. Thus

\begin{abstract}
in the second phase, the poem takes on an historic reach. The war of the Count and his family against the invaders would become a war of reconquest, of liberation and consequently of the constitution of a national homeland over a territory (Torrents 1995, p. 250).
\end{abstract}

The expulsion of the Moors in symbolic-historical terms from Catalonia is fused with the expulsion of the spirits from the mountain of Canigó, and thus Catalonia comes into being:

Glory to the Lord! Now we have our homeland/ how high it is, how strong its awakening/ behold how it rests on the Pyrenees/ its head in the sky, its feet in the sea/ [...] Oh homeland, victory gives you its wings/ like a sun of gold your star arises/ throw westwards the chariot of your glory/ arise, with God's impulse, oh Catalonia, onwards/ 


\begin{abstract}
Onwards, through the mountains, land and sea, do not stop/ the Pyrenees are already too small for your throne/ for being great today, you shall awake/ In the shadow of the cross (Verdaguer 1997, p. 234).
\end{abstract}

Had Verdaguer stopped at this point, 'Canigó would have remained an epic composition of adventures of war and love of spirits and knights' (Torrents 1995, p. 250) in the geographical setting of the Pyrenees and the historical lands conquered by Jaume I in the distant, medieval past. However, Verdaguer converts Canigó into an 'allegory of the origins of the Catalan nation projected on to the Renaixença of the Restoration period of the end of the nineteenth century' (Torrents 1995, p. 249), and in this respect, the figure of Oliba takes on capital importance, in that his appearance allows Verdaguer to move the geographical centre of the work to Ripoll, which in the Romantic-inspired construction of Catalonia had become the symbol of the origins of Catalonia, since it is here that the remains of the founders of the Catalan dynasty are kept. Thus, Canigó tells of how, in atonement for the death of Gentil, Guifré orders the construction of the monastery of St Martí on the mountain of Canigó, whose ruins inspired Verdaguer to begin the epic, and, more importantly from the point of view of the narrative, inspire the Count's brother, Oliba, to construct a monastery at Ripoll. The symbolic importance of the monastery for Verdaguer and his peers was double, since not only did it represent the resting place of the founding dynasty of Catalonia, but was also the centre of a campaign, led by the Morgades, Bishop of Vic, to have it recovered from state ownership for the Diocese of Vic after its destruction in 1835. On regaining the property for the Bishopric in 1884, Verdaguer dedicated Book 11 to Morgades, establishing a clear parallel between 
the foundation of the monastery and of Catalonia nearly a thousand years before, and their reconstruction under Morgades, the Church and God at the end of the nineteenth century. In turn, Morgades would later recognise Verdaguer's own contribution to the reconstruction of the nation under God, crowning him with the laurels of Catalonia's national poet.

However, having fallen foul of the Church and of Bishop Morgades, Verdaguer removed the dedication for the second edition of 1901, and added an epilogue, Los Dos Campanars (The Two Bell Towers), which far from having been written in the intervening years, had in fact formed the basis of Verdaguer's first approach to Canigó, but had been removed when the work took on a different direction in terms of both narrative and ideology. Whatever the personal reasons involved for the changes to the second edition, such changes undoubtedly strengthened the relation established between the nation, its homeland and God, by reinforcing the eternity of all three. Thus, while Los Dos Campanars gives an account of how the monasteries of Canigó had long since fallen into ruins, the message is clear: 'What one century constructs, another brings it down to the earth/ but the monument of God always remains;/ and neither storm, driven snow, hatred or war/ will bring Canigó to earth/ nor tear down the lofty Pyrenees' (Verdaguer 1997, p. 243). Catalonia's past, present and future, like the homeland itself, will not depend on the longevity of man-made monuments such Ripoll, but on God and his eternal creations, the mountains.

\section{Canigó and Class Politics}

From the preceding analysis, it becomes apparent that with Canigó Verdaguer produces an epic poem that is not only a work of great literary merit, but also one 
which brings together and goes beyond many of the themes that his fellow Renaixença writers had been exploring for some time. On the one hand, Canigó provides a founding myth for Catalonia and its people that could be transposed onto nineteenth-century Catalonia and the 'refounding' of the Catalan nation. On the other, however, while this temporal dimension is undoubtedly important, it cannot be understood without reference to the spatial dimension that runs so strongly throughout the work. Particularly with the changes introduced in the second edition of Canigó, the Pyrenees and rural Catalonia in general are at once a symbol of God's presence and the spiritual reserve of the Catalan nation.

While this kind of Romantic-inspired conception of the nation was by no means unique in Europe at the time, the pertinent question in the Catalan case is why did Catalan nationalism, a movement closely associated with the interests of the Barcelona industrial bourgeoisie (Solé-Tura 1970; Vilar 1979; Fradera 1992; and Marfany 1995) who stood to gain most from the process of capitalist modernisation, seek to construct the Catalan nation around conservative, 'ruralist' and anti-capitalist values? (Fradera 1992).

Of course, this situation is only a paradox if we approach it from an economic determinist perspective that effectively reduces nationalism and its manifestations to the expression of dominant material forces. A dialectical approach, on the other hand, by understanding nationalism as the terrain on which economic, political and ideological struggles take place, allows us to explain the political and ideological compromises involved in forming historical blocs around the hegemonic pretensions of a specific class. This can be clearly seen in the case of nineteenth-century Catalonia, where the industrial bourgeoisie was faced with a most difficult task of developing industrial capitalism while ensuring social order 
and stability. The liberalisation process of the Spanish state, which included the introduction of capitalist property relations in the agricultural sector, made the Catalan countryside into a dangerous place for most of the nineteenth century. Revolts were common, as were full-scale wars: between 1826 and 1874 four different wars, fought in the name of Carlism, erupted within Catalonia. Nominally, the Carlists wars were wars of succession, although the Carlists were fiercely traditionalist, advocating the official status of Catholicism within the Spanish empire and the defence of the fueros, the political and economic privileges that the Basque Country and Navarre still enjoyed and that Catalonia had lost in 1714, and consequently were against economic and political modernization. Whatever the degree of conflict in Catalonia, be it war or merely 'political brigandage' (Carr 1990, p. 340), the consequences were equally harmful for the industrial bourgeoisie: their factories and other productive infrastructure located outside urban centres became targets for the sectors of the population discontented with the process of modernization.

Rural unrest was accompanied by urban conflict. The socio-economic situation of many urban social sectors, particularly in Barcelona, was notoriously bad. Such misery was directly proportionate to the radical nature of working-class politics; in Barcelona, particularly in the textile industry, strikes were frequent, machines were wrecked and even urban guerrilla warfare erupted (Carr 1990).

However, while such conflicts were not unique to Catalonia at that time, a further problem arose: the Catalan industrial bourgeoisie was unable to rely on a supportive, powerful, modernised state to ensure relatively peaceful management of such conflicts. On the one hand, the Spanish state was dominated by landowning and commercial interests, unsympathetic to the problems of an emerging 
industrial society (de Riquer i Permanyer 2001), and on the other, the inherent weaknesses of the state apparatus meant that the use of force was often the only way in which the state would intervene in the management of class conflicts, and only when it could muster sufficient force (Fontana 1998).

In this context, the Catalan industrial bourgeoisie could only achieve hegemony by constructing alliances or historical blocs with other groups in society, and this could only be done by making political and ideological compromises towards them. The groups in question were conservative sectors of society that had supported Carlism, such as urban artisans and the rural world of small-holders, clergy, old-fashioned bureaucrats, tradesmen whose skills had been outdated by industry, lawyers, and the minor nobility who were unwilling or unable to take advantage of the emerging capitalist order (Fontana 1998, p. 271). Their importance to the hegemonic project of the bourgeoisie was two-fold: on the one hand, their defence of private property meant that they were the 'ally par excellence of the industrial bourgeoisie against the urban masses' (Fradera 1985, p. 24); on the other, their incorporation into the hegemonic project of the bourgeoisie represented a way of pacifying rural Catalonia.

Verdaguer's personal contribution to this building of bridges between these two worlds should not be underestimated. On the one hand, running through his work is a duality that makes this bridging possible: his writing about rural life and the mountains was essentially from an urban, Romantic perspective that glorified landscapes that had always been looked on with suspicion and dread by those living close by. Yet at the same time, his work constructed a vision of the nation in which those rural sectors were given a privileged position as the spiritual reserve of the nation. On the other, Verdaguer's personal trajectory is of undoubted 


\section{Conclusion}

The historic centrality of Jacint Verdaguer to Catalan nationalism can be explained, from a dialectical perspective, by his ability to construct a geographical narrative that at once contributed to and reflected the rise to power of the Catalan industrial bourgeoisie based in and around Barcelona. As this group sought to consolidate its political and economic power, so it encountered important sources of opposition: from the generally weak and unsympathetic Spanish state, and from rural and urban resistance to the centralisation of political power and the introduction of capitalism. The vision of the relationship between nation and territory that emerged through the work of writers such as Verdaguer, together with his personal biography, were key factors in the construction of a historic bloc 
between the industrial bourgeoisie and the property-owning classes of rural Catalonia against rural and working-class resistance.

In this way, dialectical approaches to nationalism not only shed new light on Catalan nationalism but also, I believe, have broader implications for the study of nationalism in general. Nationalism is inextricably tied up with ideology, and as such we must able to come to terms theoretically with key questions surrounding this concept, such as its relationship with broader political struggles and underlying structural changes in the relations of production, and the role of individual agency in cultural and ideological production. From a dialectical approach, writers such as Verdaguer are not reduced to the status as mere pawns of the ruling classes, nor are they understood as privileged conveyors of underlying ethnic forces somehow divorced from the socio-economic context in which they operated. Rather, by stressing the dialectics of human agency and structures, of politics and ideology on the one hand, and economic structures on the other, cultural production can be appreciated in terms of its aesthetic value and yet understood within the context of broader power struggles occurring in specific spatial and temporal contexts. 


\section{Notes}

\footnotetext{
${ }^{1}$ Territories, according to Robert Sack, are delimited areas or spaces that come into being 'when its boundaries are used to affect behaviour by controlling access, for example to resources or power' (1986, p. 19).

${ }^{2}$ Several authors have highlighted the importance of territory for nationalism in general (see, for example, Johnston, Knight and Kofman 1988; and Anderson, J. 1988; Kaiser 2001; Yiftachel
} 2001); Jan Penrose (2002) has discussed the role of territory in nationalist thought from Rousseau and Herder onwards; while Margaret Moore $(1998 ; 2001)$ has analysed, from a normative point of view, nationalist claims over territory. At the same time, numerous studies exist that emphasize the spatial dimension of national identity (see, for example, Osborne 1988; Lasserre 1993; the contributions in Hooson 1994; Kaufmann 1998; Kaufmann and Zimmer 1998; Nogué and Vicente 2004).

${ }^{3}$ Not all scholars agree on this point. Steven Grosby, for example, argues that examples can be found in Antiquity of peoples drawing their collective identity from territories which is explained from a putative primordial perspective, that is, people attribute certain life-giving qualities to their attachment to the land (2002, p. 192).

${ }^{4}$ The Jocs Florals can be considered the Catalan equivalent of the Welsh-language festival, the Eisteddfod

${ }^{5}$ In the original Catalan, the word 'muntanya' - 'mountain' in the singular, is used, and would find its idiomatic equivalent in the English term 'countryside'.

${ }^{6}$ The idea of the bon pagès is inspired in pairalism, a traditionalist school of thought that sought to portray an idealised, harmonic picture of rural life and of the social and economic relations that formed part of it.

${ }^{7}$ The extent of the Catalan homeland has been a much-debated issue within nationalist circles. By the late nineteenth century, Enric Prat de la Riba talked of 'Greater Catalonia', including Valencia and the Balearic Islands, while another key figure of Catalan nationalism, Antoni Rovira i Virgili, makes explicit reference to the spread of the Renaixença to such regions. Of course, if the Catalan 
nation is defined in historical - dating back to medieval times - and linguistic terms, then it is quite logical to think of the homeland in these extended terms. However, such logic has come up against powerful opposing forces: lack of popular identification/support in these regions for els Països Catalans; political and economic elites with strong ties to the Spanish state centred in Madrid; and the 1978 Constitution that explicitly prohibits the federation of Spanish regions. Consequently, while the Països Catalans continues to be the spatial frame of reference of minority nationalist groups, both inside and outside Catalonia, more moderate, mainstream nationalist have renounced the political project of this extended homeland, although they continue to stress cultural and linguistic ties. 


\section{References}

AGNEW, JOHN 1987 Place and Politics: The Geographical Mediation of State and Society, Boston: Allen and Unwin

ANDERSON, JAMES 1988 'Nationalist Ideology and Territory', in Richard Johnston, David Knight and Eleonore Kofman (eds), Nationalism, SelfDetermination and Political Geography, London: Croom Helm, pp. 18-39

BALCELLS, ALBERT 1992 Història del Nacionalisme Català: dels origens al nostre temps, Barcelona: Generalitat de Catalunya

BILLIG, MICHAEL 1995 Banal Nationalism, London: Sage BRUBAKER, ROGERS 1992 Citizenship and Nationhood in France and Germany. Cambridge, MA: Harvard University Press

CARR, RAYMOND 1990 Spain: 1808-1975, $2^{\text {nd }}$ edn, Oxford: Oxford University Press $\left[1^{\text {st }}\right.$ edn 1966$]$

CONVERSI, DANIELE 1997 The Basques and the Catalans. London: Hurst and Co.

COUNCIL OF EUROPE 1999 Framework Convention for the Protection of National Minorities, Strasbourg: Council of Europe Publishing.

CRESSWELL, TIM 2004 Place: a short introduction, Oxford: Blackwell

DE RIQUER I PERMANYER, BORJA 2001 Escolta, Espanya. La cuestión catalana en la época liberal, Madrid: Marcial Pons

FONTANA, JOSEP 1998 Història de Catalunya (Vol. 5): La Fi de l'Antic Règim i la Industrialització (1787-1868), 2nd edn, Barcelona: Edicions 62 [1st edn, 1988] FRADERA, JOSEP-MARIA 1985 'El Vigantisme en la Transformació de les Tradicions Culturals i Polítiques de la Catalunya Muntanyesa (1865-1900)', in Maties Ramisa, Els Orígens del Catalanisme Conservador $i$ "La Veu del 
Montserrat”, 1878-1900, Vic: Eumo Editorial, pp. 19-51

-- 1992 Cultura Nacional en una Societat Dividida, Barcelona: Curial

GEARY, PATRICK J. 2002 The Myth of Nations: The Medieval Origins of Europe, Princeton, NJ: Princeton University Press

GELLNER, ERNEST 1983 Nations and Nationalism, Oxford: Basil Blackwell GRAMSCI, ANTONIO 1971 Selections from the Prison Notebooks, edited by Quintin Hoare and Geoffrey Nowell-Smith, London: Lawrence and Wishart.

GROSBY, STEVEN 2002 Biblical Ideas of Nationalism: Ancient and Modern, Winona Lake, Indiana: Eisenbrauns.

GUIBERNAU, MONTSERRAT 2002 El Nacionalisme català: franquisme, transició i democràcia, Barcelona: Pòrtic

HECHTER, MICHAEL 1975 Interal Colonialism: The Celtic Fringe in British National Development, 1576-1966, Berkeley: University of California Press.

HOOSON, DAVID (ed.) 1994 Geography and National Identity, Oxford: Basil Blackwell

HROCH, MIROSLAV (1985) The Social Preconditions of National Revival in Europe: a comparative analysis of the social composition of patriotic groups among the smaller European nations, Cambridge: Cambridge University Press

JOHNSTON, RICHARD, KNIGHT, DAVID and KOFMAN, ELEONORE 1988 'Nationalism, Self -Determination and the World Political Map: An Introduction', in Richard Johnston, David Knight, and Eleonore Kofman (eds) Nationalism, SelfDetermination and Political Geography, London: Croom Helm, pp. 1-17

KAISER, ROBERT J. 1994 The Geography of Nationalism in Russia and the USSR, Princeton, N.J.: Princeton University Press

-- 2001 'Geography', in Alexander J. Motyl (ed) Encyclopedia of Nationalism: 
Fundamental Themes, vol. 1, San Diego, CA: Academic Press, pp. 315-33

KARK, CHRISTOPHER 2007 'From Parlor to Politics: Catalan Romantic

Nationalism as a Bourgeois Political Instrument' LLJournal, vol 2, no 2,

http://ojs.gc.cuny.edu/index.php/lljournal/article/viewFile/289/346

KAUFMANN, ERIC 1998 “Naturalizing the Nation”: The Rise of Naturalistic Nationalism in the United States and Canada', Comparative Studies in Society and History, vol. 40, no. 4, pp. 666-95

-- and ZIMMER, OLIVER 1998 'In search of the authentic nation: landscape and national identity in Canada and Switzerland', Nations and Nationalism, vol. 4, no. 4, pp. $483-510$

KOHN, HANS 1944 The Idea of Nationalism, New York: Collier

LASSERRE, FREDERIC 1993 'Paysage, peinture et nationalisme', Géographie et Cultures, no. 8, pp. 51-70

LOWENTHAL, DAVID 1994 'European and English Landscapes as Symbols', in David Hooson (ed.), Geography and National Identity, Oxford: Blackwell, pp. 1538

McROBERTS, KENNETH 2001 Catalonia: nation building without a state, Oxford: Oxford University Press

MAC LAUGHLIN, JIM 1986 'The Political Geography of 'Nation-Building' and Nationalism in Social Sciences: structural vs. dialectical accounts', Political Geography Quarterly, vol. 5, no. 4, pp. 299-329.

-- 2001 Reimagining the Nation-State: The Contested Terrains of Nation Building, London: Pluto Press.

MANN, MICHAEL 1993 The Sources of Social Power (Vol. II): The rise of classes and nation-states, 1760-1914, Cambridge: Cambridge University Press 
MARFANY, JOAN-LLUÍS 1995 La Cultura del Catalanisme: El nacionalisme català en els seus inicis, Barcelona: Editorial Empúries

MOORE, MARGARET (ed.) 1998 National Self Determination and Secession, Oxford: Oxford University Press

-- 2001 The Ethics of Nationalism, Oxford: Oxford University Press

NAIRN, TOM 1997 Faces of Nationalism: Janus Revisited, London: Verso

NOGUÉ i FONT, JOAN 1991 Els Nacionalismes i el Territori, Barcelona: El Llamp

-- and VICENTE, JOAN 2004 'Landscape and national identity in Catalonia', Political Geography, vol. 23, no. 2, pp. 113-32

OSBORNE, BRIAN 1988 'The iconography of nationhood in Canadian art', in Denis Cosgrove and Stephen Daniels (eds) The Iconography of Landscape. Esaays on the symbolic representation, design and use of past environments, Cambridge: Cambridge University Press, pp. 162-78

PAASI, ANSSI 1995 Territories, Boundaries and Consciousness. The Changing Geographies of the Finnish-Russian Border, Chichester: John Wiley

PENROSE, JAN 2002 'Nations, states and homelands: territory and territoriality in nationalist thought', Nations and Nationalism, vol. 8, no. 3, pp. 277-297

PI DE CABANYES, ORIOL 1984 Apunts d'Història de la Renaixença, Sant Boi de LLobregat, Barcelona: Edicions del Mall RAMISA, MATIES 1985 Els Orígens del Catalanisme Conservador i “La Veu del Montserrat”, 1878-1900, Vic: Eumo Editorial

ROSE, G. 1995 'Place and identity: a sense of place', in Doreen Massey and Pat Jess (eds.) A Place in the World: Places, Cultures and Globalization, Oxford: Open University/Oxford University Press. 
SACK, ROBERT DAVID 1986 Human Territoriality: Its theory and history, Cambridge: Cambridge University Press

SMALL, MELVIN and SINGER, DAVID 1982 Resort to Arms: International and Civil Wars, 1816-1980, London: Sage

SMITH, ANTHONY D. 2004 The Antiquity of Nations, Cambridge: Polity

SOLÉ-TURA, JORDI 1970 Catalanismo y Revolución Burguesa, Madrid: Edicusa

STALIN, JOSEF 1975 Marxism and the National Question, Calcutta: Mass Publications [first published in Russian in 1913]

STOREY, DAVID 2001 Territory: the Claiming of Space, Harlow: Prentice Hall.

TAYLOR, PETER J. 1999 Modernities: A Geohistorical Interpretation, Cambridge: Polity Press

TORRAS I BAGES, JOSEP 1981 La Tradició Catalana, Barcelona: Edicions 62 and 'La Caixa' [1st edn, Barcelona: La Ilustración, 1892]

TORRENTS, RICARD 1995 Verdaguer. Estudis i Aproximacions, Vic: Eumo Editorial

VERDAGUER, JACINT 1997 Canigó, legenda pirenaica del temps de la Reconquesta, Barcelona: Quaderns Crema [1st edn, 1886]

VILAR, PIERRE 1979 Catalunya dins L'Espanya Moderna: Recerques sobre els Fonaments Econòmics de les Estuctures Nacionals, Barcelona: Curial, Edicions 62

WEBER, EUGEN 1976 Peasants into Frenchmen: the modernization of rural France, 1870-1914, Stanford, CA: Stanford University Press

WILLIAMS, COLIN H. and SMITH, ANTHONY D. 1983 'The National Construction of Social Space', Progress in Human Geography, vol. 7, no. 4, pp. 
$502-18$

WILLIAMS, RAYMOND 1973 'Base and Superstructure in Marxist Cultural Theory', New Left Review, 82, pp. 3-16

YIFTACHEL, OREN 2001 'The Homeland and Nationalism' in Alexander J. Motyl (ed) Encyclopedia of Nationalism: Fundamental Themes, vol. 1, San Diego, CA: Academic Press, pp. 359-383

JOHN ETHERINGTON is Lecturer in the Department of Political Science and Public Law at the Universitat Autònoma de Barcelona.

ADDRESS: Departament de Ciència Política i Dret Públic, Edifici B, Campus UAB, 08193 Bellaterra (Barcelona), Spain. Email: john.etherington@uab.es 